\title{
Gender Differences in Using Arabizi Among Jordanian Undergraduate Students: A Socio- Linguistic Study
}

\author{
Mahmoud Radwan Bardaweel \\ School of Arts, Jadara University, Jordan \\ Luqman M Rababah \\ School of Arts, Jadara University, Irbid, P. O. BOX 733, Postal Code 20110, Jordan
}

\begin{abstract}
This study aimed to explore the statistical differences between each gender in using Arabizi according to their age, place of living. The sample of the study consisted (283) students selected randomly from both Yarmouk and Jadara universities. A quantitative method approach was employed by the researchers in order to answer the questions of the study. A fourteen-item questionnaire was adapted, developed and validated based on the past literature and data collection in order to achieve the purpose of the study. The results showed that there are statistically significant differences at $(\alpha=0.05)$ due to the gender variable in favor of females, and regarding the age variable the preference is in favor 19-24 age group, and no preference found related to the place of living. The study recommends examining other students who study different majors in these two universities or in other universities located in/ out the geographic region.
\end{abstract}

Index Terms-Arabizi, code switching, sociolinguistics, psycholinguistics, language development

\section{INTRODUCTION}

Language is thought to be a cognitive and individual process through which the learner is exposed to understandable knowledge, given opportunities to compromise, and given negative feedback. According to most psycholinguistic approaches to language acquisition (Carlos, 2008), a learner must be open to input. Krashen's (1985) input theory is one of the most well-known hypotheses. When a learner is subjected to comprehensible input, this hypothesis predicts how likely he or she will pick up a language. As a result, feedback can be a single move to maximize the chances of comprehension.Long (1997) claims that when learners communicate and use various types of modifications (comprehension tests, validation checks, and clarification requests) to solve connectivity breakdowns, feedback comprehensibility improves. Long's study picked the attention of so-called interactionists, who began to look at how speakers alter their speech and interaction habits to help their interlocutors to engage, comprehend, and maintain the flow of interactions. The psycholinguistics methodology focuses on what people know as they speak, how they learn that information, and how they use that knowledge. The core method to psycholinguistics theory, according to Matlin (1994), is how people learn a language biologically and what transformational laws allow people to understand the language. This suggests that in language acquisition, developmentally acceptable teaching must be considered.

Developments such as the expansion of educational opportunities at all levels of society, globalization, and mass media have all contributed to the development of a multilingual world. Another scale is demographic transition, which has coalesced to produce a huge growth in bilingualism around the world. When the preceding innovations are added together, the result is a global phenomenon known as bilingualism. Allehaiby (2013) stated that due to the globalization nowadays, Arab people tend to use a new language which is Arabizi, the substitution of English letters and numbers for Arabic letters, and it is obvious that the use of Arabizi is varied in many different field. The use of Arabizi ensures that this variety of language will continue to be widely used by Arabic native speakers and might pave its way to be used more and more by the coming generations and different social media users. Al-Khatib \& Sabbah (2008) confirmed this newly appeared phenomenon will in the long run dominate all ways of communication on social media platforms. Crystal (2001) stated that the internet is recently making verities in languages as well as it provides new opportunities for any personal activity; even though there is a popular mythology that the internet is not good for the future of language. Crystal (2001) added that it is impossible to speak about the amount of the developments which ultimately become permanent features affecting languages in general and any language in particular, and as well it is impossible to predict language change; we just recognize it when it has occurred.

Moreover, Warschauer \& Zohry (2002) explained the dominance of the use of English on the internet telling that it can possibly affect the shape and the form of the local languages and cultures; and according to crystal (2001) there would be an obvious ambiguity risk when people in the long far start using abbreviations and a collection of certain social phrases on the internet. Ghanem, (2011) added that this globalization, we have been through, has had different 
impacts on both Arabic language, and Arab culture, all of this ultimately led to the invention of Arabizi as a result from adapting the younger Arab generations the traditional Arabic along with English numerals in their internet chatting, and cell phone texting. It is illustrated in Yaghan (2008) study that the term Arabizi originally came from "arabi" (Arabic) and "inglizi" (English) and stated that this phenomenon is developed and chosen by the members of the society and not by an elite group scholars.

However, although Arabizi is used widely nowadays in our society by different classes and by different aged genders, it is doubtlessly becoming an issue of interest subjected by the researchers to explore. Hence so far and to the best of the researchers' knowledge, no empirical studies have been conducted from a socio-psycholinguistic perspective regarding which gender tend to use this phenomenon more among Jadara and Yarmouk English students. By examining these different feedbacks using the quantitative approach, it would be easy for educators and researchers to get a better understanding of the gender differences in using Arabizi among the English literature and translation students based on certain variables such as age, and place of living.

\section{LITERATURE REVIEW}

Arabizi is the process of replacing of Arabic letters by English letters and numbers (Al-Shaer, 2016). As to Saide (2019), the world has undergone many significant changes during the $21^{\text {st }}$ century, and these changes affected the lives of Arab people. The advancements, innovations, and globalization efforts brought from the new technology have driven the Arab world to get mixed with the western civilization. The Arab world is marked with unique traditions, religious beliefs, and some moral principles differ from the western ones.

Sociolinguists are interested in elucidating and explaining why some people speak differently in some different social contexts. Furthermore, they are keen to identify the way language is used to convey social meanings and the social functions of language (Holmes, 2013). By examining and identifying how people use language in various social contexts provides plenty of information about how language works, the social relationships in a community, and how people construct and convey their social identity through their language. Milroy (1995) reiterates that switching sometimes takes place between utterances and even between one utterance.

Al Heeti \& Al Abdely (2016) stated that several researches argued that code switching is usually used by people who speak more than one language in order to accomplish certain communicative intentions in their daily conversations with others, and the functions of code switching as understood revolve around three main functions which are social, psychological, and linguistic motivations, and many researches indicate that social motivation is the prime cause for switching. Speakers use other languages for the aim of communication to convey their messages quickly and easily. When speakers are unable to recall the words, phrases, or information in their mother tongue they will switch to another language and take words and phrases from it; because of the rare use of these words in their original language and these foreign words and phrases are utilized widely in their society.

With relation to the psychological function of code switching as stated also in Al Heeti \& Al Abdely (2016), some speakers in Arab societies employ code switching as a way to avoid embarrassment in some situations e.g. some people tend to say sorry instead of saying أسف, and when they express their gratitude some people say thanks or thank you instead of saying أشكر; some speakers say such expressions because they believe that they would affect the way that others may value them. There are also many studies on Arabizi as a new phenomenon appeared recently in our society and the term Arabizi according to Attawa (2012), it has originally come from the process of blending two words Arabic and the word Inglizee ( the Arabic equivalent to English ).

Relevant Studies

It is found in the study of Bani-Ismail (2012) that Arabizi is not the favorite language used by undergraduate students, and they prefer the standard Arabic as their practical style of writing; it is just used when there is a need for it. It is used as a way of communication among the students to chat with each other on some social media platforms as Twitter and Facebook. Furthermore, It is also stated it is refused by the sample to use Arabizi as a way for academic writing and that the sample admires and respects the standard Arabic.

Asserting this a study carried out by Zuhair (2015) to check the effects of Arabizi on the developments of $9^{\text {th }}$ grade English writing skills, he explains that English is the language used mostly in different parts of the globe, and because that English is spoken as a second language besides the original mother tongue, people need to be able to write, speak, and read it; so that they will be able to access and identify other sciences. Currently English is dominating mostly all disciplines of teaching and researches in all Jordanian universities, many problems arose from using English besides the original mother tongue which is Arabic; such problem is the appearance of Arabizi which is the process of blending the two words "Arabic" and "Inglizi" and it is widely spreading in the informal use of the students. Zuhair's (2015) study also reveals that Arabizi was commonly and highly used among students and this is because of the weakness and poor writing skills, and it became a habit and a stylish language among the students themselves as it is used in their everyday life. He also added that the continuous and the long run use of this informal language will in the long term future affect the their academic study; this is because it is needed from them to use formal writing at universities and that the students will not be able to learn new vocabularies of English since they are limited to that newly invented way of communication. 
It is stated in Sulliva (2017) that as the world began over the last decade to access the technology increasingly; the Arab youths started to write and communicate their spoken language on different media platforms such as Facebook, Twitter, and other Computer Mediated Communications (CMC). Also because of this the Arab youths realized that early technology couldn't help them accommodate Arabic scripts, so they started to adopt their own language in order to concord the online spaces. Instead of using pure Arabic scripts they used Latin letters and numerals representing sounds that are not exist in English such as, the number 3 represents the letter $(\varepsilon)$ in Arabic which isn't originally exist in English. Additionally, to note that this way of writing isn't a standardized approach; it differs from one country to another based on the dialect spoken there, since these Latin characters don' have the exact equivalent in English; this way of writing is known Arabizi.

Furthermore, Abandah, Khedher, Anati, Zghoul, Ababneh, \& Hattab (2015) state that the internet and smart phones are spreading the world wide, and due to this there is a high percentage of Jordanians are communicating nowadays through the mobile messages and different social media platforms, and there is a great concern referred to the language and the quality of the language used in different social media platforms and how to improve it.

furthermore, they added that there are indicators reveal that the internet contributions made by Arabic language through various social media platforms are increasing; however, there are great concerns referred to the type of English language and it's quality used in different social media platforms and how the language got affected by the internet and vice-versa; the main findings of the study reveal that the bilingualism problem was manifested in Facebook and twitter with $24 \%$ showing that $14 \%$ of the bilingual problem is in English of it $6.4 \%$ is the percentage of the English words used in the analyzed Arabic sample, and 13.2 is the percent of the messages were written in Arabizi.

Yet Arabic is the official language used by Jordanians English is used commonly among many Jordanians and this drove them to use "Arabizi" which is a mixture of two languages Arabic and English in their on line texts (Bahrainwala, 2011; Bianchi, 2012).

The findings and the results of the study carried out by Darwish (2017) shows that local Arabic language dominates the online use and interactions among the Arab youths, then comes the language of mixed standard Arabic. Arab youths justified the common use of local language and mixed language and the less use of standard Arabic: 1) Because they think it is a way to attract the others, it helps them to speak out their ideas freely, and because it is considered a practical way of communication 2) The standard and classical Arabic is not frequent and common among them. 3) Those who graduated from private high school insist on and prefer using mixed language or foreign languages. 4) Arab youths are looking for a new way of communication. 5) It is a habit and they consider it a different style.

After reviewing the previous studies, one can observe that the vast majority of these studies focus on the form of language (Allehaiby, 2013), language choice and code switching (Al-Khatib\&Sabbah2008), the threats of Arabizi on Arabic language and Arab societies, the threat of Arabizi to Arabic (Al-Shaer, 2016), the dominance of Arabizi in different media platforms (Darwish, 2013), the reasons for using Arabizi online among Saudi Arabian youths (Alghamdi\&Petraki2018) the threats of Arabizi on Arabic language (Ghanem, 2011), and the effects of the internet on language choice (Abandah et al,2015). Few studies have examined the gender differences in using Arabizi. Thus, study is unique because it provides a comprehensive understanding of the gender differences in using Arabizi among Jadara and Yarmouk English students based on certain variables such as sex, social class, and age. This study bridges a gap in the previous literature which lacks these variables.

\section{METHODS}

This study is in quantitative method approach. According to Creswell (2014), quantitative approach provides statistical and numerical outputs regarding the experiments; examples of the instruments are survey, questionnaire, checklists, tests, or you may use to observe somebody's behavior. It can be used according to him to respond to certain relational variables within the research and the finding results can be explanatory, predictive, or confirming. This study has been conducted in both English literature and Translation departments in both Jadara and Yarmouk Universities. A permission has been gained from both universities to allow the researchers to enter both departments and disseminate the questionnaire. The sample of the study of students is a about $20 \%$ of the students who study English language and translation from a total number 2000 students for the academic year 2019/2020. Furthermore, he students of this study are all native Arabic speakers and they learned English as a foreign language. The sample of this study contained 283 participants chosen randomly from males and females students who study at Jadara and Yarmouk Universities locate at Irbid governorate. The Participants are all aged between (19 - 39) years old sophomore, junior, senior students, and master students representing nearly $(20 \%)$ of the total population; their mother tongue is Arabic language and they all learned English as a foreign language, furthermore these students are studying English language and literature, Translation, English language, and English literature.

\section{A. Characteristics of the Participants}


TABLE 1

The PARTicipants' Distribution BASEd On Age, Gender, Place Of Living

\begin{tabular}{|c|c|c|c|c|c|c|}
\hline \multicolumn{3}{|c|}{ Variables } & \multicolumn{2}{|c|}{ Number } & Percent & Total \\
\hline \multirow[t]{4}{*}{ Age ( for both gender ) } & \multicolumn{2}{|l|}{$19-24$} & \multicolumn{2}{|c|}{111} & $39.2 \%$ & \multirow[t]{4}{*}{283} \\
\hline & \multicolumn{2}{|l|}{$25-29$} & \multicolumn{2}{|l|}{103} & $36.4 \%$ & \\
\hline & \multicolumn{2}{|l|}{$30-34$} & \multicolumn{2}{|l|}{59} & $20.8 \%$ & \\
\hline & \multicolumn{2}{|l|}{$35-39$} & \multicolumn{2}{|l|}{10} & $3.5 \%$ & \\
\hline \multirow[t]{4}{*}{ Gender } & \multirow[t]{2}{*}{ Male } & Yarmouk & 97 & \multirow[t]{2}{*}{141} & 49.8 & \multirow[t]{4}{*}{283} \\
\hline & & Jadara & 44 & & & \\
\hline & \multirow[t]{2}{*}{ Female } & Yarmouk & 98 & \multirow[t]{2}{*}{142} & 50.2 & \\
\hline & & Jadara & 44 & & & \\
\hline \multirow[t]{8}{*}{ Place of Living } & \multicolumn{2}{|l|}{ Irbid } & \multicolumn{2}{|l|}{93} & $32.9 \%$ & \multirow[t]{8}{*}{283} \\
\hline & \multicolumn{2}{|l|}{ Ajlun } & \multicolumn{2}{|l|}{65} & $23.0 \%$ & \\
\hline & \multicolumn{2}{|l|}{ Jerash } & \multicolumn{2}{|l|}{56} & $19.8 \%$ & \\
\hline & \multicolumn{2}{|l|}{ Mafraq } & \multicolumn{2}{|l|}{18} & $6.4 \%$ & \\
\hline & \multicolumn{2}{|l|}{ Amman } & \multicolumn{2}{|l|}{19} & $6.7 \%$ & \\
\hline & \multicolumn{2}{|l|}{ Zarka } & \multicolumn{2}{|l|}{19} & $6.7 \%$ & \\
\hline & \multicolumn{2}{|l|}{ Madaba } & \multirow{2}{*}{\multicolumn{2}{|c|}{$\begin{array}{l}8 \\
5\end{array}$}} & $2.8 \%$ & \\
\hline & \multicolumn{2}{|l|}{ Salt } & & & $1.8 \%$ & \\
\hline
\end{tabular}

As shown above in table 1, 141 of the participants are male, representing (49.8) \% of the whole sample; whereas 142 participants are female representing (50.2) \% representing the whole study sample. Regarding the age 111 participants are aged between 19-24 years old which consists $39.2 \%$ of the total sample; 103 participants are aged between 25-29 years old which consists $36.4 \%$ of the total sample; 59 participants are aged between 30-34 years old which consists $20.8 \%$ of the total sample, and 10 participants are aged between 35-39 years old which consists $3.5 \%$ of the total sample. Finally, according to the place of living 93 participants live in Irbid governorate which consists $32.8 \%$ of the total study; 65 participants live in Ajlun governorate which consists $23 \%$ of the total study; 56 participants live in Jerash governorate which consists $19.8 \%$ of the total study; 19 participants live in Amman governorate which consists $6.7 \%$ of the total study; 19 participants live in Zarka governorate which consists $6.7 \%$ of the total study; 18 participants live in Mafraq governorate which consists $6.3 \%$ of the total study; 8 participants live in Madaba governorate which consists $2.8 \%$ of the total study, and finally 5 participants live in Salt governorate which consists $1.8 \%$ of the total study.

\section{B. Data Collection}

The type of the instrument used in this study concluded after reviewing the past literature and the previous studies; eventually the researchers concluded that the suitable and the most appropriate instrument for this study is the questionnaire. The questionnaire used in this study was adapted, administered in, developed, and put into 14 items. The questionnaire has been designed and scored using a five 5 Likert scale and they are as follow: $5=$ strongly agree $4=$ Agree 3 = Neutral 2 = disagree $1=$ Strongly Disagree

The data in this study involves a questionnaire which was distributed to 283 students from both genders (male and female).The purpose of the questionnaire is to disclose the data regarding gender, age, and place of living. The validity of the instrument was evaluated after being presented to panel of experts consisting of three members. All of them are English linguistic doctors. They are all professional, well experienced, and competent enough; and after the recommendations given; the researchers made certain amendments and modifications to the instrument accordingly. The percentage of the agreement between all the panel of experts was set at (88.5\%) which is considered an acceptable percentage to fulfill the objectives of the research (see table 1).

TABLE 2

PANEL OF THE EXPERTS

\begin{tabular}{|l|l|c|l|l|}
\hline Name & Rank & $\begin{array}{l}\text { Years } \\
\text { experience }\end{array}$ & of & University \\
\hline Lutfi Abulhaija & Associate professor & 30 & Yarmouk & Lutfi_a@yu.edu.jo \\
\hline Mohammad Saraireh & Associate professor & 30 & Yarmouk & Saraireh@yu.edu.jo \\
\hline Majdi Abu Dalbuh & Assistant professor & 20 & Yarmouk & Majdi.a@yu.edu.jo \\
\hline
\end{tabular}

For the sake of establishing the reliability of the questionnaire the searcher conducted a pilot case study (Test Retest), which consists of (50) participants from the same population and not from the same sample; same questionnaire items are shared after two weeks from the first time distribution. The internal consistency was tested by Cronbach's alpha, see table 3. 
TABLE 3

COEFFICIENT OF THE INTERNAL CONSISTENCY

\begin{tabular}{|l|l|}
\hline Reliability Statistics & N of Items \\
\hline Cronbach's Alpha & 14 \\
\hline 0.740 & \\
\hline
\end{tabular}

Table 3 confirms the validity of the questionnaire in answering the questions of the study, where it's Cronbach's Alpha coefficient reaches to $74.0 \%$. And the obtained values are considered sufficient and fair enough for the aims of the study.

\section{Data Analysis}

To answer the first question of the study the researchers used the Standard deviations, percentages, means, frequencies, statistical figures, and Friedman test. And to answer the second question one way ANOVA and T-test were employed to measure the differences between which gender male or female tend to use this phenomenon more based on certain variables such as age and place of living.

\section{RESULTS AND DisCUSSIONS}

In order to achieve the objectives of the study; the major results of the study are presented in the following categories, and each study question is introduced in each subsection. The identified results related to the purpose of the study are presented clearly here in the upcoming analysis after analyzing and processing the obtained data as the quantitative method approach was used by the researchers using a statistical number technique. Based on that all the results being clarified in this study reflects a real facts regarding the use of Arabizi among Jadara and Yarmouk English students, the common motivations for code switching, the statistical differences between males and females in using Arabizi, and the statistical differences between males and females in using Arabizi with respect to age and place of living.

\section{A. The First Research Question: Are There Any Statistical Differences at $\alpha=0.05$ between Males and Females in Using Arabizi?}

To answer the question, the researchers have used percentages, means, statistical figures, as shown in tables 4 and 5 below. The question concerns the differences between which gender male or female in using Arabizi and to answer this question and after processing the outputs using the SPSS a Group Statistics table has been concluded as indicated in table 4 below.

TABLE 4

REASONS BEYOND USING ARABIZI AMONG JORDANIAN UNIVERSITY STUDENT

\begin{tabular}{|c|c|c|c|c|c|}
\hline KEASUNS BEYUN & USING $A$ & MUNC & DANIAN & ESITY STUDENI & \\
\hline Group Statistics & & & & & \\
\hline Gender & & $\mathrm{N}$ & Mean & Std. Deviation & Std. Error Mean \\
\hline The reasons beyond using Arabizi among & Male & 141 & 2.9108 & 0.75623 & 0.06369 \\
\hline $\begin{array}{l}\text { Jordanian University students( Jadara and } \\
\text { Yarmouk ) }\end{array}$ & Female & 142 & 3.0931 & 0.34049 & 0.02857 \\
\hline
\end{tabular}

Table 4 indicates that there is a virtual difference between the means for males and females in the reasons behind using Arabizi among Jordanian University students (Jadara and Yarmouk) in which the total participants from males who participated in the survey questionnaire is 141 and the mean for them reaches 2.9108 and the standard deviation for the male participants reaches 0.75623 as shown in table 4 .

Regarding the total participants from Female who participated in the questionnaire is 142 and the mean for them reaches 3.0931 and the standard deviation for the female participants reaches 0.34049 as shown in table 4 .

These results can be as well indicated as follow: 


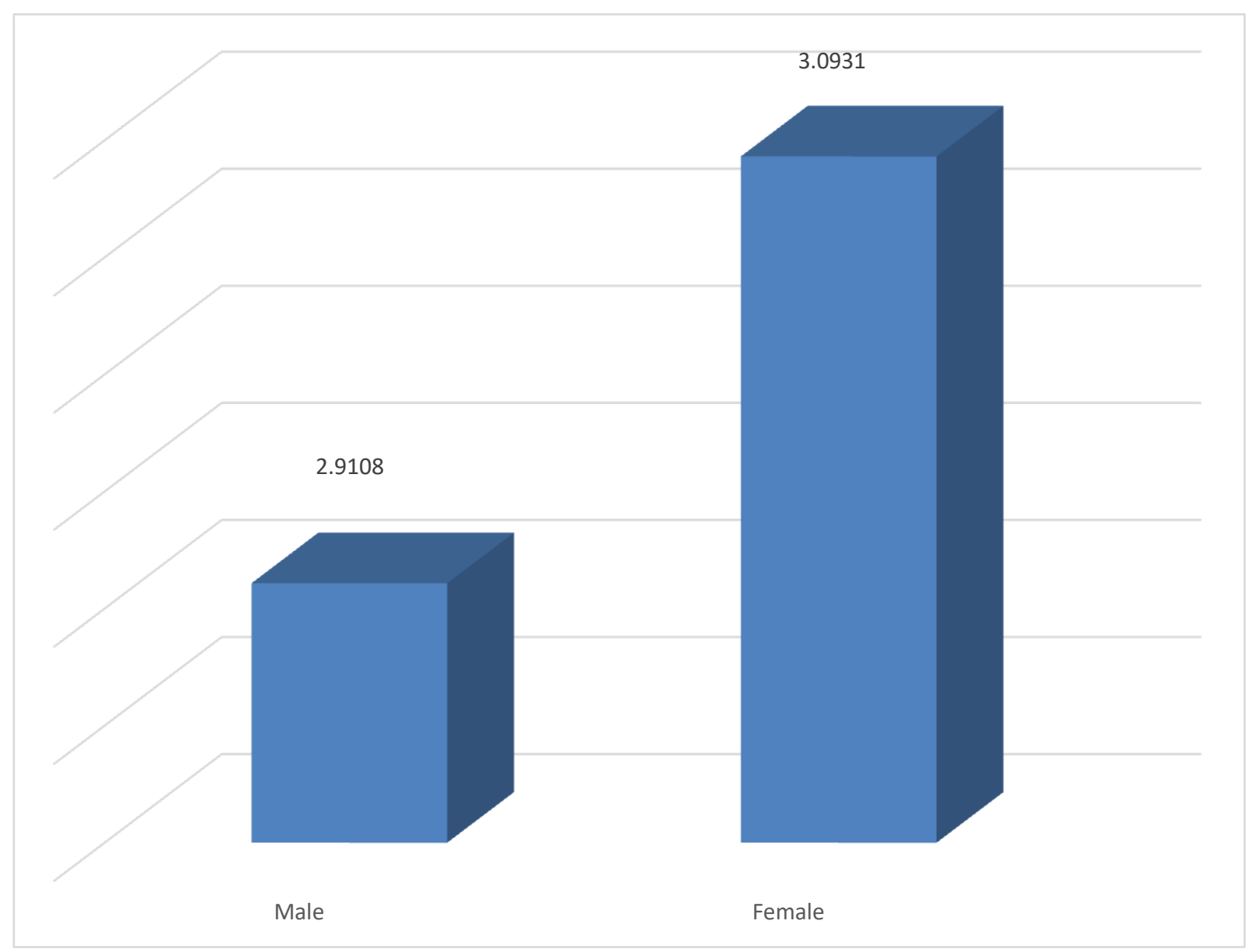

Figure 1. Diagram Presentation for the Gender Differences

The above diagram shows that females are marked with high percentage in using Arabizi in our society than males and this fact basically gained from the obtained outputs of the questionnaire.

TABLE 5

Results of LEVEn's Test For The EQuAlity Of VARIANCES AMONG MALES AND Females In Using ARABIZI Independent Samples Test

\begin{tabular}{|c|c|c|c|c|c|c|c|c|c|c|}
\hline & & \multicolumn{2}{|c|}{$\begin{array}{l}\text { Levene's Test for } \\
\text { Equality of } \\
\text { Variances }\end{array}$} & \multicolumn{7}{|c|}{ t-test for Equality of Means } \\
\hline & & \multirow[t]{2}{*}{$\mathrm{F}$} & \multirow[t]{2}{*}{ Sig. } & \multirow[t]{2}{*}{$\mathrm{T}$} & \multirow[t]{2}{*}{ Df } & \multirow[t]{2}{*}{$\begin{array}{l}\text { Sig. (2- } \\
\text { tailed) }\end{array}$} & \multirow[t]{2}{*}{$\begin{array}{l}\text { Mean } \\
\text { Difference }\end{array}$} & \multirow[t]{2}{*}{$\begin{array}{l}\text { Std. Error } \\
\text { Difference }\end{array}$} & \multicolumn{2}{|c|}{$\begin{array}{l}95 \% \text { Confidence } \\
\text { Interval of the } \\
\text { Difference }\end{array}$} \\
\hline & & & & & & & & & Lower & Upper \\
\hline \multirow{2}{*}{$\begin{array}{l}\text { the reasons beyond using } \\
\text { Arabizi among Jordanian } \\
\text { University } \\
\text { students( Jadara and } \\
\text { Yarmouk ) }\end{array}$} & $\begin{array}{l}\text { Equal variances } \\
\text { assumed }\end{array}$ & 38.199 & 0.000 & -2.617 & 281 & 0.009 & -0.18222 & 0.06964 & -0.31930 & $\overline{0}-04514$ \\
\hline & $\begin{array}{l}\text { Equal variances } \\
\text { not assumed }\end{array}$ & & & -2.610 & 194.222 & 0.010 & -0.18222 & 0.06980 & -0.31988 & $\overline{0} .04455$ \\
\hline
\end{tabular}

$$
\alpha=0.05
$$

For the reasons beyond using Arabizi among Jordanian University students (Jadara and Yarmouk), the previous table indicates that the $\mathrm{p}$-value of Levene's Test is (less than 0.01) less than 0.05, which means that the two variances are not equal. The p-value of the t-test is $(\mathbf{0 . 0 1 0})$ less than 0.05 , so we can reject the null hypothesis, and accept the alternative one which refers to that there are significant differences between males and females in using Arabizi with level of significance $95 \%$.

B. The Second Question of The Study: Are There any Statistical Differences at $\alpha=0.05$ between Males and Females in using Arabizi with Respect to Age and Place of Living?

To answer the question of the study the researchers have divided it into two categories fist category relates to the age, and the second category relates to the place of living.

1. The first part of the fourth question: Are there any statistical differences at $\alpha=0.05$ between males and females in 
using Arabizi with respect to the age?

To answer this question one-way ANOVA test has been done, where the null hypothesis refers to that the means are equal at all age groups, the alternative hypothesis refers to that at least one group has a different mean from the other group, the results are indicated as follows in table 6:

TABLE 6

ONE WAY NOVA RESULTS ACCORDING TO AGE VARIABLE

\begin{tabular}{|c|c|c|c|c|c|}
\hline \multicolumn{6}{|c|}{ ANOVA } \\
\hline \multicolumn{6}{|c|}{ The reasons beyond using Arabizi among Jordanian University students (Jadara and Yarmouk ) } \\
\hline & Sum of Squares & Df & Mean Square & $\mathrm{F}$ & Sig. \\
\hline Between Groups & 48.264 & 3 & 16.088 & 88.892 & 0.000 \\
\hline Total & 98.759 & 282 & & & \\
\hline
\end{tabular}

Table 6 indicates that the p-value of the test (less than 0.01) less than 0.05 , so we can reject the null hypothesis, and accept the alternative one which refers to that there is significant differences between students in using Arabizi related to their age. To check the significant differences between each two Age group LSD test has been done, the results are indicated as follows:

TABLE 7

RESUlts OF LSD FOR POST HOC TEST FoR AGE VARIABLE

\begin{tabular}{|c|c|c|c|c|}
\hline \multicolumn{5}{|c|}{ KESULIS UF LSD FUR PUS I HUC IESI } \\
\hline \multicolumn{5}{|c|}{$\begin{array}{l}\text { Dependent Variable: The reasons beyond using Arabizi among Jordanian University students( Jadara and } \\
\text { Yarmouk ) }\end{array}$} \\
\hline (I) Age & (J) Age & Mean Difference (I-J) & Std. Error & Sig. \\
\hline \multirow[t]{3}{*}{$19-24$} & $25-29$ & $.54020^{*}$ & .05820 & .000 \\
\hline & $30-34$ & $.54034^{*}$ & .06854 & .000 \\
\hline & $35-39$ & $2.05560^{*}$ & .14046 & .000 \\
\hline \multirow[t]{3}{*}{$25-29$} & $19-24$ & $-.54020^{*}$ & .05820 & .000 \\
\hline & $30-34$ & .00014 & .06946 & .998 \\
\hline & $35-39$ & $1.51540^{*}$ & .14091 & .000 \\
\hline \multirow[t]{3}{*}{$30-34$} & $19-24$ & $-.54034^{*}$ & .06854 & .000 \\
\hline & $25-29$ & -.00014 & .06946 & .998 \\
\hline & $35-39$ & $1.51525^{*}$ & .14549 & .000 \\
\hline \multirow[t]{3}{*}{$35-39$} & $19-24$ & $-2.05560^{*}$ & .14046 & .000 \\
\hline & $25-29$ & $-1.51540^{*}$ & .14091 & .000 \\
\hline & $30-34$ & $-1.51525^{*}$ & .14549 & .000 \\
\hline
\end{tabular}

Table 7 indicates that there is a significant difference found between each two age groups where the p-value of all tests is less than 0.01 .

- $\quad$ For age group 19-24:

- $\quad$ It has a positive significant difference with group 25-29 related to the age group 19-24

- It has a positive significant difference with group 30-34 related to the age group 19-24

- It has a positive significant difference with group 35-39 related to the age group 19-24

- $\quad$ For age group 25-29:

- $\quad$ It has a positive difference with group 30-34 related to the age group 25-29

- $\quad$ It has a positive significant difference with group 35-39 related to the age group 25-29

- $\quad$ For age group 30-34:

- $\quad$ It has a positive significant difference with group 35-39 related to the age group 30-34.

As can be seen from table 7 that the preference is for the first age group over all age groups, which is from 19-24, and this is because the significant field is less than 0.05 , and this means that this difference is important, and that all the inputs of the Mean Difference are all positive, and this gives us an indication that the priority is for this category.

When looking at the second category of table 7 which is from 25-29, it is possible to notice that it has no preference over the first age group which is from 19-24 and that the Mean Difference is in the negative case and this indicates that the preference for the first age group when compared to the second age group. However, there is an advantage for the second age group at the expense of the third and fourth age groups, because the Mean Difference is in the positive case, which means that the preference for the second age group when compared to the third and fourth age group

As for the third age group, it has no preference over the first and second age groups, but it has an advantage over the fourth category, because the Mean Difference entries aren't in the positive case.

This is because the common preferred language for texting. There are a number of reasons that might be responsible for the wide use of Arabizi among this age group which is 19 - 24. Among these reasons are: euphemism, prestige, unfamiliarity with Arabic, Academic, Scientific and technical terms, the ability to use abbreviations and acronyms and the attractiveness of English language. 
using Arabizi with respect to place of living?

To answer this question one-way ANOVA test has been done, where the null hypothesis refers to that the means are equal at all groups of place of living, the alternative hypothesis refers to that at least one group have a different mean from the other group, the results are indicated as follows:

TABLE 8

ONE WAy ANOVA Results ACCORDING To Place Of LiVING VARIABLE

\begin{tabular}{|l|l|l|l|l|l|}
\hline ANOVA \\
\hline The reasons beyond using Arabizi among Jordanian University students( Jadara and Yarmouk ) \\
\hline Setween Groups & Sum of Squares & Df & Mean Square & F & Sig. \\
\hline Within Groups & 2.590 & 7 & 0.370 & 1.058 & 0.391 \\
\hline Total & 96.169 & 275 & 0.350 & & \\
\hline
\end{tabular}

Table 8 indicates that the p-value of the test $(\mathbf{0 . 3 9 1})$ greater than 0.05 , so we can accept the null hypothesis which refer to that there aren't any differences between students in using Arabizi related to their place of living.

\section{CONCLUSION AND RECOMMENDATIONS}

The aims of the study were to explore and investigate the socio-psycholinguistic perspective of gender differences in using Arabizi among students of Jadara and Yarmouk universities. Using a questionnaire sample adapted and developed by the researchers based on previous researches and literature, basically the corpus of the study included students who study English and translation majors from both Yarmouk and Jadara universities.

The study aims to allocate and identify the reasons that prompt university students to use this newly appeared phenomenon and the common motivations for code switching, in addition to find out the gender differences in using it based on certain variables such as age, and place of living. This study answers the calls made by (Alghamdi \& Petraki, 2018; Al-Shaer 2016; Darwish 2013 and Al-Khatib, \& Sabbah 2008). By examining the level of using Arabizi among Yarmouk and Jadara English students, and after analyzing the outcomes obtained from a questionnaire distributed to nearly $20 \%$ of the total students applying SPSS analysis and ANOVA test the researchers have come to conclude the following:

It is also indicated in this study that Females are using Arabizi more than Males where the Mean Rank after processing the data indicates that 3.0932 is for females and 2.9108 is for males.

Moreover; this study indicates that the there is a significant difference between each age group in using Arabizi and the preference is for 19 - 24 age group, after it comes the second age group which is from 25-29, then comes $30-34$ age group, and finally comes 35 - 39 age group. Finally no difference found after the analysis of the data related to the place of living.

\section{A. Limitations and Implications}

This study is limited to both Yarmouk (public) and Jadara (private) universities and both of them locate in Irbid governorate in the north part of Jordan. The sample of the study was limited to the students who study English language and translation in both Jadara and Yarmouk universities. This study was conducted on nearly $20 \%$ of the students who study English, and Translation in both Universities. This study was limited to the students who are aged between 19 To 39. However, better for future studies to take into consideration the dynamic and progress changes in the modern technology which affect all ways of communication and this ultimately plays an important role on the use of such informal language.

\section{B. Recommendations}

1. As this study was limited to Irbid governorate which locates in the northern part of Jordan, there is a need as well to examine the gender differences and also the reasons in different geographic regions in Jordan.

2. As this study just includes only the students who study English and translation from both Yarmouk and Jadara universities, there is a need to examine other students who study different majors in these two universities or in other universities locate in/ out the geographic region.

3. Conducting more studies on the possible future threats of Arabizi on Arabic language.

\section{REFERENCES}

[1] Abandah, G., Khedher, M., Anati, W., Zghoul, A., Ababneh, S., \&Hattab, M. S. (2015). The Arabic Language Status in the Jordanian Social Networking and Mobile Phone Communications. Presented In the $7^{\text {th }}$ Int'l Conference on Information Technology (ICIT 2015) (pp. 449-456).http://dx.doi.org/10.15849/icit.2015.0083

[2] Al-Bayati, R. (2018). Arabglish: Writing Arabic in English. Eton Institute. Retrieved from:https://etoninstitute.com/wplogin.php?redirect_to=https\%3A\%2F\%2Fetoninstitute.com\%2Fblog\%2Farabizi.(August , 2019 )

[3] Alghamdi, H., \&Petraki, E. (2018).Arabizi in Saudi Arabia: A Deviant Form of Language or Simply a Form of Expression?. Social Sciences, 7(9), 155-165.http://dx.doi.org/10.3390/socsci7090155 
[4] Al Heeti, N., \& Al Abdely, A. A. (2016). Types and functions of code-switching in the English language used by Iraqi doctors in formal settings. International Journal of Advanced Research and Review, 1(8), 10-18.

[5] Al-Khatib, M., \& Sabbah, E. H. (2008). Language choice in mobile text messages among Jordanian university students. $S K Y$ Journal of Linguistics, 21(1), 37-65.

[6] Al-Khawaldeh, M., Al-Khawaldeh, N., Bani-Khair, B.\& Algwery, H. (2016). Mechatronics Engineers' perception of Code mixing: Philadelphia University and Hashemite University as a case study. International Journal of Applied Linguistics \& English Literature,5(7),110-117.http://dx.doi.org/10.7575/aiac.ijalel.v.5n.7p.110

[7] Almwajeh, M., \& Rababah, L. (2019). There is more to it than meets the eye: an intercultural study of religious speech acts between Jordanian and American students. International Journal of Linguistics, 11 (1), 34-45. https://doi.org/10.5296/ijl.v11i1.14261

[8] Allehaiby, W. H. (2013). Arabizi: An Analysis of the Romanization of the Arabic Script from a Sociolinguistic Perspective. Arab World English Journal, 4(3), 52-62.

[9] Al-Shaer, I. M. (2016).Does Arabizi Constitute a threat to Arabic?.Arab World English Journal, 4(3), 18-30. http://dx.doi.org/10.2139/ssrn.2859238

[10] Alshboul, N, \& Rababah, L. (2021).The emoji linguistic functions on Facebook interactions among undergraduate students at Jadara University in Jordan. Journal for the Study of English Linguistics, 9 (1), 43-54.http://dx.doi.org/10.5296/jsel.v9i1.18486

[11] Attawa, M. (2012). Arabizi: a writing variety worth learning? An exploratory study of the views of foreign learners of Arabic on Arabizi.(Unpublished MA thesis).AUC, Cairo.

[12] Bahrainwala, L. (2011). You say Hello, I say Mar7aba: Exploring the digi-speak that powered the Arab revolution. Michigan State University. Rhetoric and Writing.

[13] Bani-Ismail, I. T. M. (2012). Arabizi as Used by Undergraduate Students in Some Jordanian Universities: A Sociolinguistic Study (Doctoral dissertation), Yarmouk University.

[14] Banikalef, A., \& Rababah, L. (2018). Gender differences and emotional expressiveness on Facebook: An analysis of prosodic features among Jordanian Facebookers. Studies in Linguistics and Literature, 2(3), 180-184. http://dx.doi.org/10.22158/sll .v2n3p18

[15] Bianchi, R. M. (2012). 3arabizi-When local Arabic meets global English. Acta Linguistica Asiatica, 2(1), 89100.http://dx.doi.org/10.4312/ala.2.1.89-100

[16] Claros, M.S.C. (2008). Psycho-linguistic and socio-cultural approaches to language learning: A never ending debate. Colombian Applied Linguistics Journal, 10(1), 142-154.http://dx.doi.org/10.14483/22487085.102

[17] Creswell, J. W. (2014). Educational research: Planning, conducting, and evaluating quantitative Research (4th Ed.). Pearson Education.

[18] Crystal, D. (2001). Language and the Internet. Cambridge: Cambridge University Press.

[19] Darwish, E. B. (2017). Factors influencing the uses, diglossia and attrition of Arabic language in social media: Arab youth case. Journal of Education and Social Sciences, 7(1), 250-257.

[20] Ghanem, R., (2011). Arabizi is destroying the Arabic language. Arab world. http://www.arabnews.com/node/374897. (September, 2019)

[21] Ghazal, M. (2014). Arabizi Popularity Threatening Arabic Proficiency among Native Speakers, Experts Warn. Retrieved from http://www.jordantimes.com speakersexpertswarn\#.(January, 2020)

[22] Hamdan, H. (2017). Attitudes towards Arabic Romanization and Student's Major: Evidence from the University of Jordan. Arab World English Journal (AWEJ), 7,(2), 22-53.http://dx.doi.org/10.31219/osf.io/5y3ge

[23] Holmes, J. (2013). An introduction to sociolinguistics. Routledge Taylor and Francis group.

[24] Hudson, R. A. (1996). Sociolinguistics. Cambridge university press

[25] Jdaitawi, M., Ishak. N., Taamneh, M., Gharaibeh, M., \& Rababah, L. (2011). The Effectiveness of Emotional Intelligence Training Program on Social and Academic Adjustment among First Year University Students. International Journal of Business and Social Science, 2 (24). 251-258.

[26] Kenali, A., Yusoff, N., Kenali, H., \& Kamarudin, M. (2016). Code-Mixing Consumptions among Arab Students. Creative Education, 7(7), 9-31. http://dx.doi.org/10.4236/ce.2016.77097

[27] Krashen, S.D. (1985). The input hypothesis: Issues and implications. London: Longman.

[28] Kusuma, L. B. (2014). A Study of Leetspeak Among Young Hispanic Americans in Mocospace Mobile Social Network. (Doctoral dissertation), Sanata Dharma University.

[29] Long, M. H. (1997). Construct Validity in SLA Research: A Response to Firth and Wagner. The Modern Language Journal, 81(3), 318-323.http://dx.doi.org/0.1111/j.1540-4781.1997.tb05487.x

[30] Matlin, M.M. (1994). Cognition. New York: Ted Buchholz.

[31] Milroy, J. (1995). One Speaker, Two languages: Cross-disciplinary Perspectives on Code-Switching. Cambridge University Press.

[32] Muthusamy, P. (2009). Communicative functions and reasons for code switching: A Malaysian perspective. Language \& Society, 5, 1-16.

[33] Rababah, I., Rababah, L. (2017). Investigating Arabic to Speakers of Other Languages (ASOL) Lecturers' Attitudes towards Utilizing Flipped Classroom Instruction (FCI): A Qualitative Study at Jordanian Public Universities. International Educational studies, 10 (7), 80-91. https://doi.org/10.5539/ies.v10n7p94.

[34] Rababah, L., \& Bani Melhem, N. (2015). Investigation into Strategies of Creativity in EFL Writing in Jordan. Journal of Literature, Languages and Linguistics, 5 (23), 14-25. https://doi.org/10.5539/ies.v10n7p94.

[35] Saide Jr, A. A. (2019). Arabizi-Help or Harm? An Analysis of the Impacts of Arabizi-Threat or Benefit to the Written Arabic Language? (Doctoral dissertation), University of Dayton.

[36] Sullivan, N. (2017). Writing Arabizi: Orthographic Variation in Romanized Lebanese Arabic on Twitter (Doctoral dissertation). The University of Texas: Austin 
[37] Warschauer, M., Said, G. R. E., \&Zohry, A. G. (2002). Language choice online: Globalization and identity in Egypt. Journal of Computer-Mediated Communication, 7(4).JCMC744, https://doi.org/10.1111/j.1083-6101.2002.tb00157.x

[38] Yaghan, M. A. (2008). Arabizi: A contemporary style of Arabic Slang. Design Issues, 24(2), 3952.http://dx.doi.org/10.1162/desi.2008.24.2.39

[39] Zuhair, A. (2015). The Effect of Arabism of Romanic Alphabets on the Development of 9th Grade English as a Foreign Language Students' Writing Skills at Secondary School Level. Journal of Education and Practice, 6(36), 91-95.

Mahmoud R. Bardaweel; Jerash- Jordan sep- 1987; Master of Art English Language and Literature Jadara university; Irbid Jordan;2020.He works as a language lecturer and as an interpreter in The Royal Police Academy in the language institute; Amman Jordan; he teaches English for different levels of students ( Elementary, pre-intermediate, intermediate, upper-intermediate, and advanced level in English). He worked as Police Advisor in UNMID mission The African Union-United Nations Hybrid Operation in Darfur -Sudan;2016-2018; He worked there as a head of R\&R Unit ( Reform and Restructure) and as a trainer teaching different UN topic aspects concerning mission land procedures such as (Human Rights, Gender, Woman Empowerment, professionalism, and Respect for Diversity).

Luqman Rababah, $\mathrm{PhD}$, is an Associate Professor of Applied Linguistics within the School of English Language \& Translation, Jadara University, Jordan, where he teaches courses on Sociolinguistics, Pragmatics and Second Language Acquisition theories. He has more than thirty publications. His research is concentrated in two areas: Second Language Acquisition theories, and writing. 